\title{
Trabzon-Akçaabat Orta Mahalle'de Yer Alan Geleneksel Türk Evlerine Ait Pencerelerin İncelenmesi
}

\author{
Bengi Deren SAKA ${ }^{1}$ iD, Necmi KAHRAMAN ${ }^{2}$ \\ ${ }^{1}$ Yüksek Lisans, Afyon Kocatepe Üniversitesi, Sosyal Bilimler Enstitüsü, İç Mimarlık ve Çevre Tasarımı, \\ Afyonkarahisar, Türkiye, bengideren@gmail.com \\ ${ }^{2}$ Dr. Öğr.Üyesi, Afyon Kocatepe Üniversitesi, Afyon Meslek Yüksekokulu, İç Mekan Tasarımı, Afyonkarahisar,
} Türkiye,nkahraman@aku.edu.tr

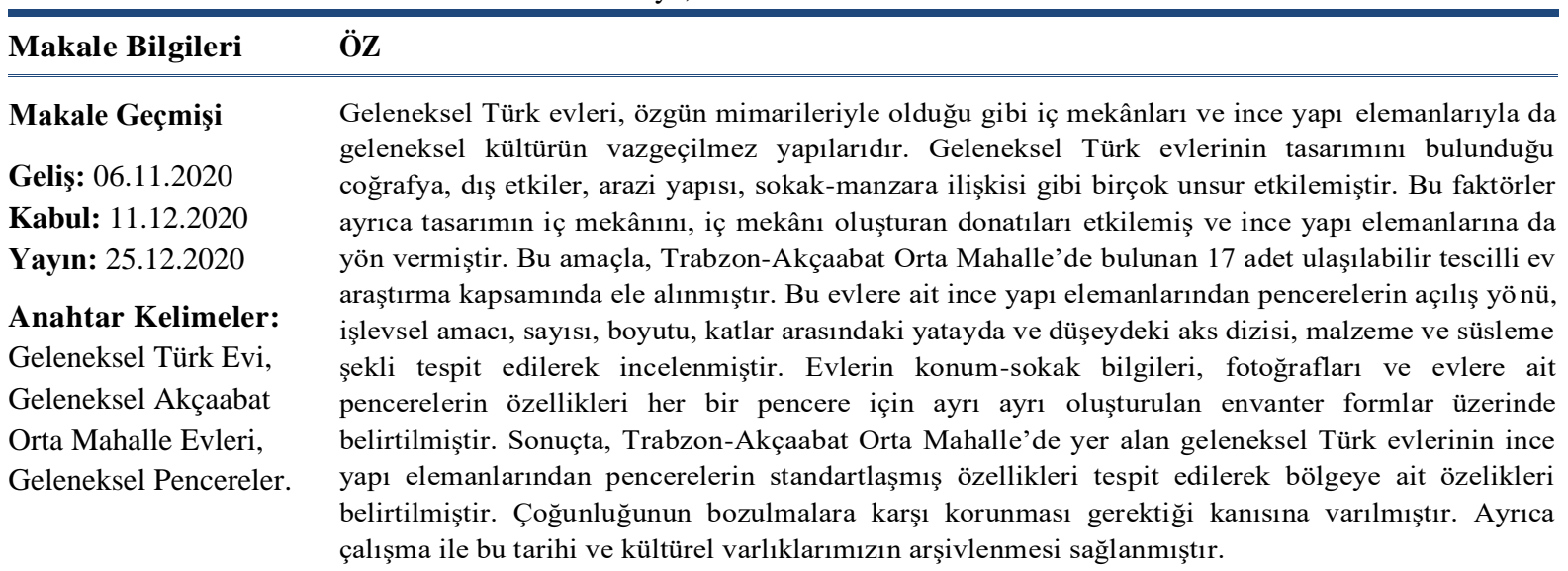

\section{Examination of the Windows of Traditional Turkish Houses in Trabzon- Akçaabat Orta Mahalle}

\begin{tabular}{|c|c|}
\hline Article Info & ABSTRACT \\
\hline $\begin{array}{l}\text { Received: } 06.11 .2020 \\
\text { Accepted: } 11.12 .2020 \\
\text { Published: } 25.12 .2020 \\
\text { Keywords: } \\
\text { TraditionalTurkish } \\
\text { House, } \\
\text { Traditional Akçaabat } \\
\text { Orta Mahalle Houses, } \\
\text { Traditional Windows. }\end{array}$ & $\begin{array}{l}\text { Traditional Turkish houses are indispensable structures of traditional culture with their interior spaces } \\
\text { and fine building elements as well as their original architecture. Many factors such as geography, } \\
\text { external effects, land structure, street-landscape relationship have affected the design of traditional } \\
\text { Turkish houses. These factors also gave direction to the interior space of the design, the fittings and } \\
\text { fine building elements that make up the interior space. For this purpose, } 17 \text { accessible registered } \\
\text { houses in Trabzon-Akçaabat Orta Mahalle were considered within the scope of the research. Among } \\
\text { the fine building elements of these houses, the opening direction of the windows, their functional } \\
\text { purpose, number, size, horizontal and vertical axis of the floors between the floors, material and } \\
\text { decoration style were determined and examined. The location and street information of the houses, } \\
\text { their photographs and the properties of the windows of the houses are indicated on the inventory forms } \\
\text { created separately for each window. As a result, standardized features of windows, one of the fine } \\
\text { structural elements of traditional Turkish houses located in Trabzon-Akçaabat Orta Mahalle, were } \\
\text { determined and the characteristics of the region were determined. It is concluded that the majority } \\
\text { should be protected against deterioration. In addition, archiving of these historical and cultural assets } \\
\text { was ensured with this study. }\end{array}$ \\
\hline
\end{tabular}

Atıf/Citation: Saka., B, D. \& Kahraman., N. (2020). Trabzon-Akçaabat Orta Mahalle'de Yer Alan Geleneksel Türk Evlerine Ait Pencerelerin İncelenmesi, Konya Sanat Dergisi, 3, 1-13.

"This article is licensed under a Creative Commons Attribution-NonCommercial 4.0 International License (CC BY-NC $4.0)$ " 


\section{GíRİș}

Geleneksel Türk evlerinde cephedeki karakteristik bütünlüğün bir parçası olan pencereler; süslemeleri, söveleri, boyutları, sıralanışları ve diğer ince yapı elemanlarıyla bütünlüğü önem arz eden unsurlardandir.

Geleneksel Türk evinde yapının konumu, tasarımı, plânı, malzeme seçimi gibi birçok faktörü etkileyen iklim-coğrafya ve kültür pencereleri de etkilemiştir. Bu doğrultuda pencerelerin özellikleri:

İç mekândaki döşeme, seki altı, sekinin şekli, yüksekliği ve pencere ile ilişkisi evde barınan kişilerin yaşam biçimleri ve dişarıyla iletişimi konusunda; kullanılan kaplama malzemeleri ve iç mekândaki diğer elemanlar hakkında bilgi verir. Pencerelerdeki ahşap ya da demir parmaklıklar, kafesler, kepenk ve tepe pencereleri de hem mahremiyet derecesine hem de yapının inşaa tarihine ilişkin bilgiler verir (Asatekin, 1994; Akt: Göğebakan: 52).

Donatıların odalardaki yerleşim düzeni ve boyutları ihtiyaca göre değişiklik göstermektedir. İnce yapı ve donatı elemanlarının boyutları insan ölçüsüne göre belirlenmiştir. Örneğin pencere ve kap1 yüksekliğinde, odayı çepeçevre dolanan ahşap sergen 'el değmesin yeter' yükseklikte tasarlanmıştır. Donatı elemanlarının yerleşim düzeni ve karakteristik özellikleri; önem, kullanım sıklığı, kullanım sırası ve depolama gibi ergonomik ilkelere göre plânlanmıştır. Türk evinde sabit donatı elemanları, mekânın eylemlere göre şekillenmesini sağlayan en önemli öğelerdir (Eldem, 1968).

Geleneksel Türk evlerinde dış etkiler, arazi yapısı, sokak-manzara ilişkisi yapının konumlanmasında etkili olduğu gibi pencerelerinde açılış yönünü, sıklığını, boyutunu etkilemektedir. Manzaraya ya da bahçeye yönelik cephelerdeki pencerelerin boyut olarak daha büyük ve sıklıkla ön cephede yer aldığı görülmektedir.

Çalışmanın amacı, Anadolu'nun birçok bölgesinde var olan, tarihsel önemi ve kendine has mimarî üslup ve ilkeler taşıyan, "Türkevinin, iç mimarlık alanında yapılan literatür taraması sırasında ince yapı elemanlarından pencerelere ait birçok seminer ve lisans tezine rastlanmış fakat bu konunun "Türk Evi" bağlamında, özellikle Doğu Karadeniz Bölgesi'ne ait örneklerde ele alınmadığ 1 tespit edilmiştir. Bu durum araştırmanın önemini ortaya koymaktadır.

\section{Türk Evinde Pencere Konumu ve Özellikleri}

Türk evinin ilk örneklerini, dışarıya açılan pencerelerden ziyade, bütün odaların iç avludan 1şık aldığ1 cephe düzeni oluşturmaktadır. İlk dönemde yapılan pencereler camsızdır. Camın yaygınlaşmasıyla iki yana açılan çerçeveler yapılmıştır (Yürekli, 1979).

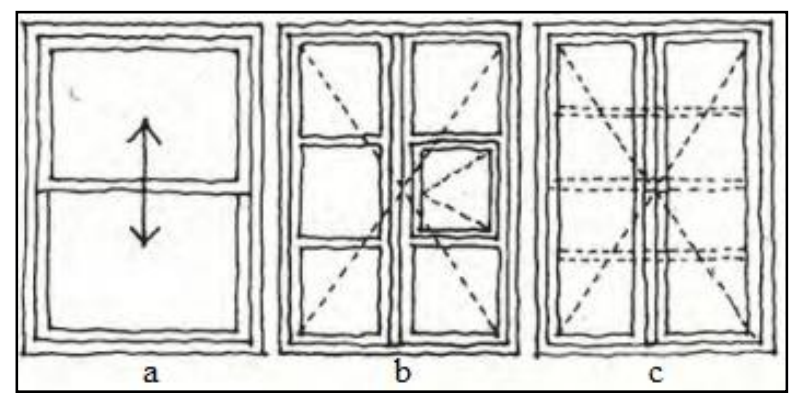

Resim1. Pencere Kanatlarının Açılma Türleri; Düşey Yönde Çalışan Kanat (a), Düşey Menteşeli Kanat (b ve c) (Küçükerman, 1998).

Hangi kanat türünün kullanılacağını belirleyen en büyük faktör iklimdir. Resim 1 b'de ifade edilen kanat içerisine uygulanan diğer küçük kanatçık çeşidi, özellikle soğuk iklim bölgelerinde inşa edilmiş Türk evlerinde iç mekânın soğumasını önlemek amacıyla uygulanmıştır (Küçükerman, 
1998).

Mahremiyet anlayışından dolayı alt kattaki pencereler boyut olarak küçük tutulmuştur. Üst kattaki pencereler ise daha sık, boyut olarak da büyük tutulup iç mekânın doğal 1şıktan daha fazla faydalanması sağlanmıştır. Bazı evlerde sadece zemin kat pencerelerinde bazen ise tüm katlardaki pencerelerde görülen pencere kafesleri ve kapakları güvenlik sağladığı gibi ayrıca görsel bütünlük oluşturarak cepheye estetik bir görünüm de katmıştır (Küçükerman, 1998).

\section{Türk Evinde Pencere Çeşitleri}

- Düşey sürme pencere (Giyotin)

İslâmiyet'in etkisiyle dişarıya açılan pencerelerden ziyade avludan 1 şık gereksinimini karşılayan cephe düzeni oluşturmuştur. İçe kapanık yaşayan Türklerde, düşey sürme pencereler batı etkisinden sonra görülmüştür. Pencerelerin, ev bütünlüğü (katlar arasında) içerisinde çeşitli biçimlerde uygulandığı görülmektedir (Küçükerman, 1998).

Aynı bölgelerde yapılmış evlerin cephesel özellikleri, pencere boyutları benzerlik gösterir.

Pencere sistemleri diştan iki yana doğru açılan ahşap kepenkler, ahşap kafes ya da demir parmaklıklar olarak tasarlanmıştır. Bu pencereler mekânın içine ve dışına belli yararları ve estetik katkıları sunacak şekilde düzenlenmiştir (Ünver, 1976; Kahraman, 1997; Arat, 2011).

Dıştan iki yana doğru açılan ahşap kepenkler güvenlik ve mahremiyet amacına bağlı kalınmadan kullanılan elemanlardır. Ahşap kafesli pencereler ise mahremiyet amaçlı kullanılmaktadır. Bu amaçla kullanılan ahşap kafesler, küçük kafesçikler bırakacak şekilde imal edilir. Güvenlik amacıyla kullanılanlarda ahşabın kesiti daha büyük ve kareler de geçilemeyecek kadar daha büyük tutulur (Kahraman, 1997; Arat, 2011).

Demir parmaklıklar yalnızca güvenlik amaçlı kullanılır. Estetik örneklerine rastlayabileceğimiz gibi günümüzde basit ve çirkin diyebileceğimiz kullanımları görülmektedir. Camlı kanatlar, mekânın içine ve dışına ayrı ayrı belli yararları ve estetik katkılar sunacak şekilde düzenlenmiştir. Bina öğesidir. Süslemeleri çoğu kez vitray olarak tasarlanmıştır. Pencerenin sağlamlığını elde etmek kaygısıyla alçı, kurşun ve beton vitraya rastlanmaktadır (Küçükerman, 1998; Kahraman, 1997; Arat, 2011).

- Tepe pencereleri

Tepe pencereleri, özellikle kalın duvarlarda, insanın erişemeyeceği yükseklikte olduğu ve açılma gereksinimi duyulmadığ 1 için sabit kanatlı yapılmaktadır. İç mekânın 1şıtan faydalanmasının yanı sıra camlarına da uygulanan süslemelerle dekoratif bir elemandır. Tepe penceresi uygulamalarında bölgesel özellikler etkendir. Özellikle Doğu Karadeniz bölgesinin yağışlı iklimi ve ahşap işleme geleneği, tepe penceresinin yorumlanmasında etkili olmuştur (Resim 2) (Eldem, 1987; Küçükerman, 1998).

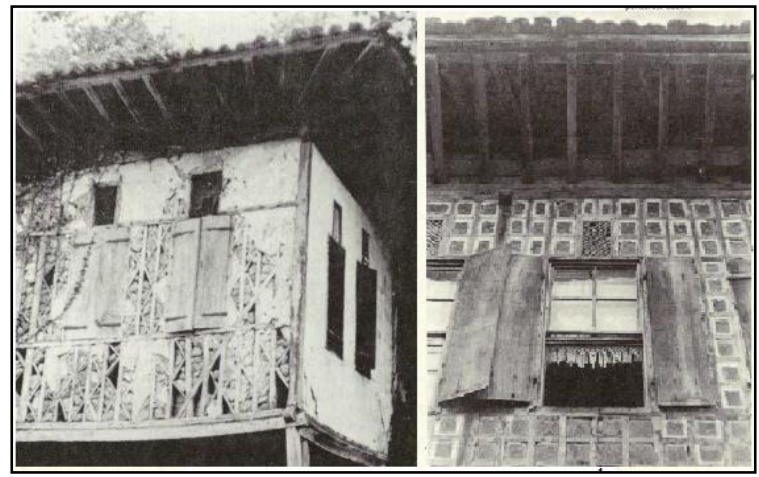

Resim 2. Türk Evi'nde Ahşap Kapaklı Tepe Penceresi, Arakl-Trabzon (Küçükerman,1985). 
- Muntabik pencere

Birçok yapı elemanı gibi tarihsel süreç içerisinde değişime uğrayan pencereler, fonksiyonel özelliğinin yanı sıra sonraki gelişiminde sanatsal olarak da düşünülmüştür. Basit dikdörtgen ve kare şekillerinin yanı sıra kemerli ve elips şekillerinde de pencereler görülmüştür. 1800'lerde ses ve 1s1 yalıtımını arttırmak için muntabık yani iki ayrı pencerenin arka arkaya yerleştirilmesi yapımı başlamıştır (Yürekli, 1979).

\section{YÖNTEM}

$\mathrm{Bu}$ çalı̧̧mada Orta Mahalle'de bulunan geleneksel Türk Evlerinin pencereleri saha araştırması yapılarak, pencerelerle ilgili boyut, süsleme, estetik özellikleri akademik çalışmalarda kabul görmüş envanter form üzerinde verilmiştir. Ev sahipleriyle yüzyüze görüşmenin yanı sıra Akçaabat Tarihi Evler Koruma Derneği Başkan Yardımcısı Ömer ORHAN, Orta Mahalle yerleşkesi, mimari yapıları ve mevkide restorasyon çalışmaları bulunan Mimar Bekir GERÇEK ve Mimar Uğur DEĞERMENCİ bilgileri ile saha araştırması derlenerek konu ile ilgili literatür taramas1 yapılmıştır.

\section{Örneklem/Çalışma}

Orta Mahalle evlerindeki 24 adet tescilli ev araştımanın evrenini, bunlardan ulaşılabilir 17 adet ev ise örneklemini oluşturmaktadır (Tablo 1).

Tablo 1. Araştırma Kapsamında İncelenen Evler

\begin{tabular}{|lcccc|}
\hline YAPININ İSMİ & Sokak & Tescil & Yapım Yılı & Kat Sayısı \\
1.Timurciler Konağı & Surt & Tescilli & $1890 \sim 1899$ & 2 \\
2.Veysel Seyis Evi & Demirci & Tescilli & $1890 \sim 1899$ & 2 \\
3.Lermioğlu Konağı & Sirt & Tescilli & $1890 \sim 1899$ & 2 \\
4.Hüsnü Efendi Konağı & Dutlu & Tescilli & $1890 \sim 1899$ & 2 \\
5.Remzi Bey Konağı & Dutlu & Tescilli & $1890 \sim 1899$ & 2 \\
6.Hayri Çolak Evi & Dutlu & Tescilli & $1890 \sim 1899$ & 1 \\
7.Mehmet Efendi Konağı & Dutlu & Tescilli & $1890 \sim 1899$ & 3 \\
8.Kanoğlu Konağ1 & Dutlu & Tescilli & $1890 \sim 1899$ & 2 \\
9.Neziroğu Konağ1 & Dutlu & Tescilli & $1890 \sim 1899$ & 2 \\
10.Ibrahim Ağa Evi & Dutlu & Tescilli & $1890 \sim 1899$ & 3 \\
11.Birincioğlu Evi & Dutlu & Tescilli & $1890 \sim 1899$ & 2 \\
12.Benzinci Mustafa Evi & Dutlu & Tescilli & $1890 \sim 1899$ & 2 \\
13.Veli Sezgin Evi & Dutlu & Tescilli & $1890 \sim 1899$ & 2 \\
14.Bekir Efendi Evi & Dutlu & Tescilli & $1890 \sim 1899$ & 2 \\
15.Sonay Çavuşoğlu Evi & Pulathane & Tescilli & $1890 \sim 1899$ & 2 \\
16.Mehmet Saltoğlu Konağ & Dutlu & Tescilli & $1890 \sim 1899$ & 2 \\
17.Ömer Türer Konağ1 & Pulathane & Tescilli & $1890 \sim 1899$ & 2 \\
\hline
\end{tabular}

\section{BULGULAR}

Orta Mahallede incelenen 17 Türkevi sonucu erişilen bulgular şunlardır: Cepheye karakteristik bir özellik katan pencereler, çıkma bulunan evlerde çıkmanın her iki yanında dizili halde bulunmaktadır. Genellikle çıkmanın kısa kenarında daha dar olarak plânlanmıştır. Alınan ölçülerin ortamla değerlerine göre genişliği 100 cm'yi geçmeyecek ve dikdörtgen şeklini bozmayacak biçimde uygulandığ 1 görülmüştür. Yörelere göre geniş̧lik ve yükseklikleri değişse de incelenen pencerelerin 1/2'lik oranı kendi içinde yakaladığı görülür. Pencereler genel olarak ahşap söve ve pervazla çevrelenmiştir. 
Mahremiyet unsuru geleneksel Türk evlerinde olduğu gibi Orta Mahalle evlerinin tasarımına dayansımıştır. Hem mahremiyet hem de güvenlik açısından zemin kattaki pencere boyutlarında küçülmeler ve parmaklıklar görülmüştür. Çoğunlukla ahşap sövelerin alınlık kısmında taç bulunmaktadır. Pervaz ve taçlar süslemeden uzak, yalındır. Dış kapının bir ya da her iki yanında pencere bulunan örneklerde, pencere söveleri dış kapının sövelerine birleştirilerek üst tarafta kemer görüntüsü oluşturulmuştur. Cephede bu durum estetik bütünlük sağlamaktadır (Resim 3).

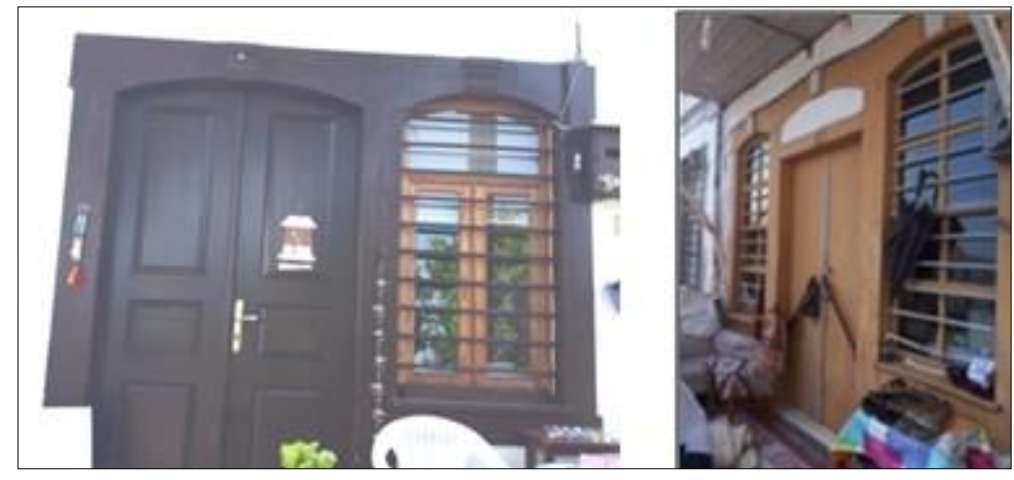

Resim 3. Birleşik Pencere ve Dış Kapı Söve Örnekleri

Kemerli pencerelerin görülmemesinin en büyük nedeni iklimin vermiş olduğu etkidir. Kemer pencere üzerinde bir nevi siperlik yaparak güneş kontrolünü sağlar. Bu durum mekânda gölge oluşturur ve gölgeyi mekâna yansıtır. Dolayısıyla sıcak bölgelerde bulunan evlerde daha çok uygulanmaktadır. Ilıman ve güneşli gün sayısı mevsim normallerinde olan Karadeniz Bölgesinde nadir olarak uygulanan pencere kemerleri ise, basık ve dardır.

Geleneksel Türk Evi'ndeki mahremiyeti sağlamak amacıyla yapılan kafesler ve kepenkler Orta Mahalle evlerinde bulunmamaktadır. Her iki katta da aynı amaç doğrultusunda yapılmış, ahşap ve demir korkuluklar görülmüştür. Bu korkuluklar ayrıca pencereleri dış hava şartlarından korumak içinde yapılır.

Pencereler zemin katta üstü sabit, altı iki kanatlı açılır şekildedir. 1.katta üstü sabit, altı iki kanatlı aç1lır olarak görülmüştür (Resim 4-5).

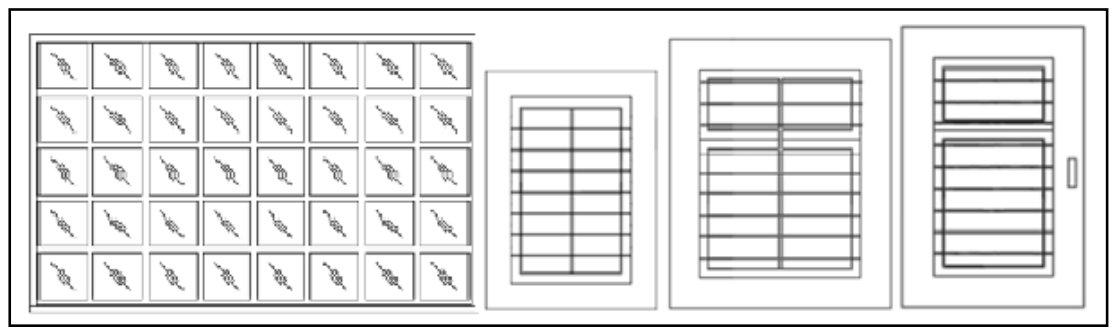

Resim 4. Orta Mahalle Evleri’nde Zemin Katta Görülen Pencereler 


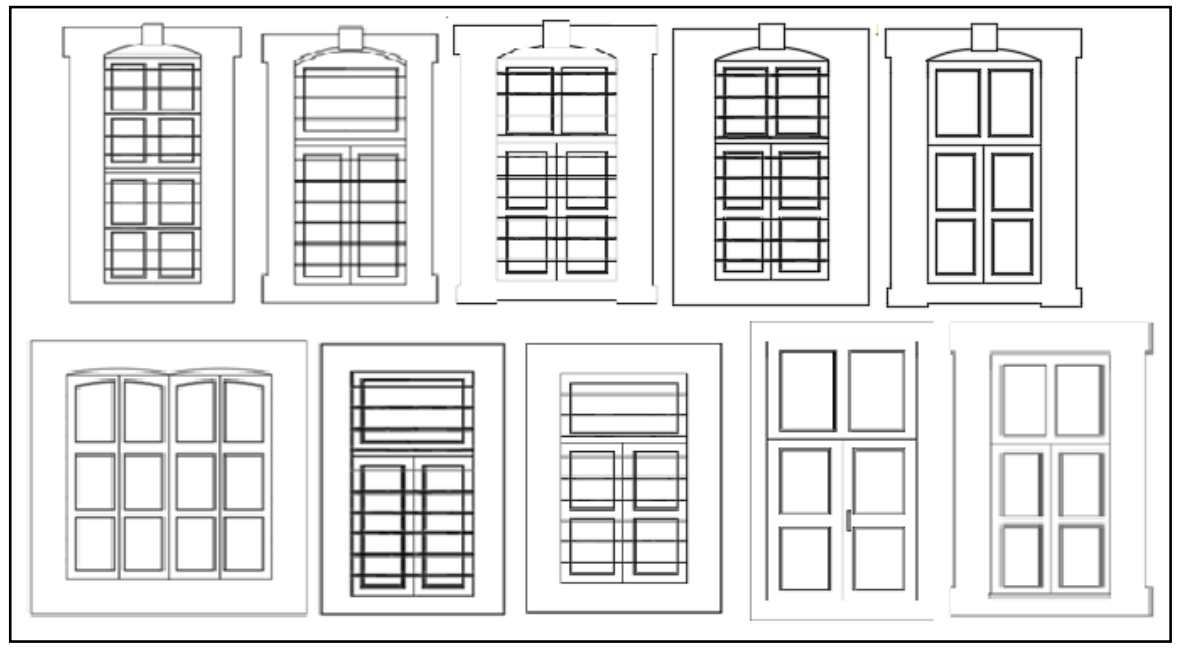

Resim 5. Orta Mahalle Evleri'nde Zemin, 1. ve 2. Katta Görülen Pencereler

Geleneksel Türk evlerinde mahremiyet konusu evlerin cephelerini, kat sayılarını, çıkmaları, pencere ve kapı düzenleri gibi birçok şeyi etkilemiştir. Çıkma bulunmayan Veysel Seyis evinin 1. katında sofa mekânının manzaraya yönelmiş duvarında mahremiyet bakış açısıyla kafeslerin küçültüldüğü görülmektedir. Bir diğer çıkma bulunmayan yapı Kanoğlu Konağı ön cephesindeki duvarda da pencere boyutu alışılagelmiş orandan daha geniş olduğu görülmektedir. Bu genişlikpencere deliklerinin daha küçük ve geometrik bölmelere ayrılıp hem estetik katkı hem de iç mekânı perdelemesi mahremiyet anlayışııın yansımasıdır (Resim 6-7).
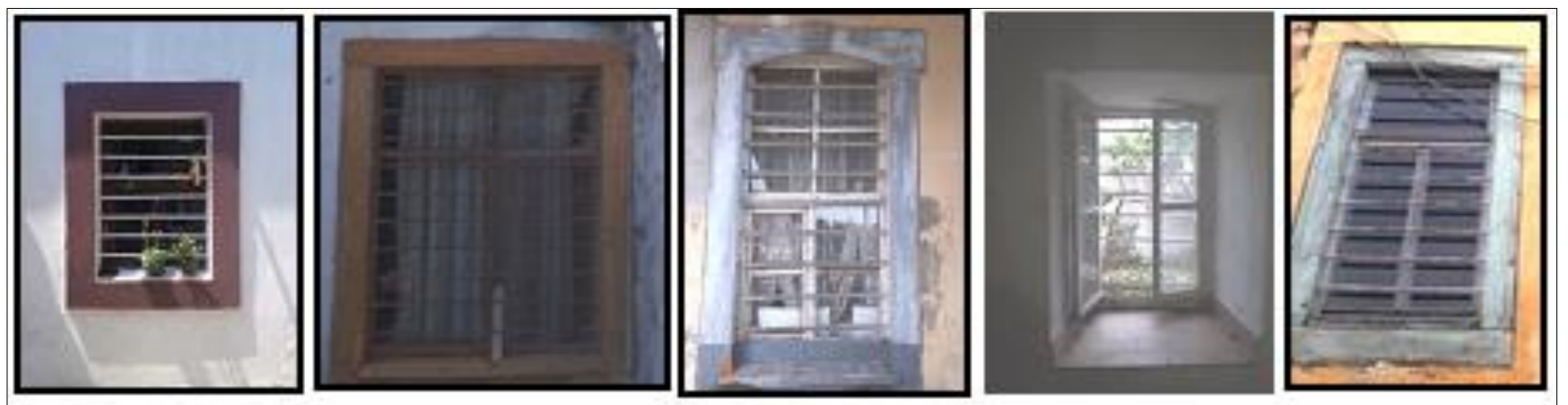

Resim 6. Orta Mahalle Evleri'nde Görülen Pencere Örnekleri
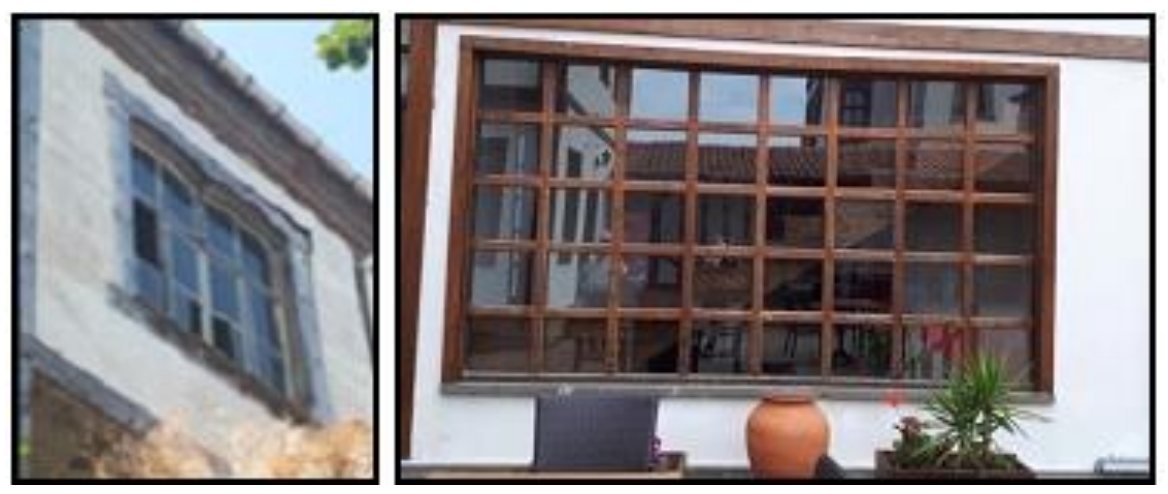

Resim 7. Orta Mahalle Evleri'nde Görülen Küçük Bölmeli Pencereler

Zemin kat ve 1 . kat pencereleri ile ilgili elde edilen veriler, yenilenme durumu, sövelerin ve kasaların malzemesi, kanat sayısı, kanat ölçüleri tablolaştırılarak ifade edilmiştir (Tablo 2-3).

Zemin katlarda ölçülen en yüksek pencere genişliği; $89 \mathrm{~cm}$, en düşük pencere genişliği $70 \mathrm{~cm}$, pencere genişliği ortalaması $80.9 \mathrm{~cm}$ ' dir. Zemin katlarda ölçülen en yüksek pencere yükssekliği; 176 $\mathrm{cm}$, en düşük pencere yüksekliği $139 \mathrm{~cm}$, pencere yüksekliği ortalaması 164,2 cm' dir (Tablo2-3). 
1. katlarda ölçülen en yüksek pencere genişliği; $97 \mathrm{~cm}$, en düşük pencere genişliği $81 \mathrm{~cm}$, pencere genişliği ortalaması $83.7 \mathrm{~cm}$ ' dir. Zemin katlarda ölçülen en yüksek pencere yüksekliği; $178 \mathrm{~cm}$, en düşük pencere yüksekliği $145 \mathrm{~cm}$, pencere yüksekliği ortalaması 166,4 cm' dir (Tablo 3).

Tablo 2. Incelenen Zemin Kat Pencerelerinin Özellikleri

\begin{tabular}{|c|c|c|c|c|c|c|c|c|c|c|}
\hline \multirow{2}{*}{ Evin Adı } & \multirow{2}{*}{ Malzeme } & \multicolumn{2}{|c|}{ Yenileme } & \multicolumn{2}{|c|}{ Kanat Sayısı } & \multicolumn{3}{|c|}{ Kanat Ölçüleri (cm) } & \multicolumn{2}{|c|}{ Taç } \\
\hline & & Var & Yok & Tek & Çift & Gen. & Yük. & Kal. & Var & Yok \\
\hline 1. Timurciler Konağ 1 & Ahşap & $\mathrm{x}$ & & & $\mathrm{x}$ & 87 & 162 & 3 & $\mathrm{x}$ & \\
\hline 2. Veysel Seyis Evi & Ahşap & & $\mathrm{x}$ & & $\mathrm{x}$ & 84 & 171 & 3 & $\mathrm{x}$ & \\
\hline 3. Lermioğlu Konağ1 & Ahşap & & $\mathrm{x}$ & & $\mathrm{x}$ & 86 & 164 & 5 & $\mathrm{x}$ & \\
\hline 4. Hüsnü Efendi Konağ 1 & Ahşap & & $\mathrm{x}$ & & $\mathrm{x}$ & 84 & 167 & 4 & $\mathrm{x}$ & \\
\hline 5. Remzi Bey Konağ 1 & Ahşap & & $\mathrm{x}$ & & $\mathrm{x}$ & 84 & 161 & 3,5 & $\mathrm{x}$ & \\
\hline 6. Hayri Çolak Evi & Ahşap & $\mathrm{x}$ & & & $\mathrm{x}$ & 76 & 139 & 3 & & $\mathrm{x}$ \\
\hline 7. Mehmet Efendi Konağ & Ahşap & & $\mathrm{x}$ & & $\mathrm{x}$ & 87 & 168 & 3 & $\mathrm{x}$ & \\
\hline 8. Kanoğlu Konağ1 & Ahşap & & $\mathrm{x}$ & & $\mathrm{x}$ & 81 & 160 & 3 & $\mathrm{x}$ & \\
\hline 9. Neziroğu Konağı & Ahşap & & $\mathrm{x}$ & & $\mathrm{x}$ & 85 & 167 & 3,5 & $\mathrm{x}$ & \\
\hline 10. İbrahim Ağa Evi & Ahşap & & $\mathrm{x}$ & & $\mathrm{x}$ & 138 & 149 & 3 & & $\mathrm{x}$ \\
\hline 11. Birincioğlu Evi & Ahşap & & $\mathrm{x}$ & & $\mathrm{x}$ & 89 & 171 & 3 & $\mathrm{x}$ & \\
\hline 12. Benzinci Mustafa Evi & Ahşap & & $\mathrm{x}$ & & $\mathrm{x}$ & 86 & 175 & 5 & $\mathrm{x}$ & \\
\hline 13. Veli Sezgin Evi & Ahşap & & $\mathrm{x}$ & & $\mathrm{x}$ & 70 & 145 & 3 & $\mathrm{x}$ & \\
\hline 14. Bekir Efendi Evi & Ahşap & & $\mathrm{x}$ & & $\mathrm{x}$ & 86 & 167 & 3 & $\mathrm{x}$ & \\
\hline 15. Sonay Çavuşoğlu Evi & Ahşap & & $\mathrm{x}$ & & $\mathrm{x}$ & 89 & 176 & 3 & $\mathrm{x}$ & \\
\hline 16. Mehmet Saltoğlu Konağ & Ahşap & & $\mathrm{x}$ & & $\mathrm{x}$ & 81 & 175 & 3 & $\mathrm{x}$ & \\
\hline 17. Ömer Türer Konağ1 & Ahşap & & $\mathrm{x}$ & & $\mathrm{x}$ & 84 & 166 & 5 & $\mathrm{x}$ & \\
\hline
\end{tabular}

Tablo 3. Incelenen 1. Kat Pencerelerinin Özellikleri

\begin{tabular}{|c|c|c|c|c|c|c|c|c|c|c|}
\hline \multirow{2}{*}{ Evin Adı } & \multirow{2}{*}{ Malzeme } & \multicolumn{2}{|c|}{ Yenileme } & \multicolumn{2}{|c|}{ Kanat Sayısı } & \multicolumn{3}{|c|}{ Kanat Ölçüleri (cm) } & \multicolumn{2}{|c|}{ Taç } \\
\hline & & Var & Yok & Tek & Çift & Gen. & Yük. & Kalın. & Var & Yok \\
\hline 1. Timurciler Konağ & Ahşap & & $\mathrm{x}$ & & $\mathrm{x}$ & 88 & 164 & 3 & $\mathrm{x}$ & \\
\hline 2. Veysel Seyis Evi & Ahşap & & $\mathrm{x}$ & & $\mathrm{x}$ & 163 & 174 & 3 & $\mathrm{x}$ & \\
\hline 3. Lermioğlu Konağ 1 & Ahşap & & $\mathrm{x}$ & & $\mathrm{x}$ & 87 & 164 & 5 & $\mathrm{x}$ & \\
\hline 4. Hüsnü Efendi Konağ & Ahşap & & $\mathrm{x}$ & & $\mathrm{x}$ & 84 & 167 & 4 & $\mathrm{x}$ & \\
\hline 5. Remzi Bey Konağ 1 & Ahşap & & $\mathrm{x}$ & & $\mathrm{x}$ & 86 & 165 & 3,5 & $\mathrm{x}$ & \\
\hline 6. Hayri Çolak Evi & - & & - & & - & - & - & - & - & \\
\hline 7. Mehmet Efendi Konağ 1 & Ahşap & & $\mathrm{x}$ & & $\mathrm{x}$ & 87 & 169 & 3 & $\mathrm{x}$ & \\
\hline 8. Kanoğlu Konağ & Ahşap & & $\mathrm{x}$ & & $\mathrm{x}$ & 81 & 167 & 3 & $\mathrm{x}$ & \\
\hline 9. Neziroğu Konağı & Ahşap & & $\mathrm{x}$ & & $\mathrm{x}$ & 85 & 145 & 3,5 & $\mathrm{x}$ & \\
\hline 10. İbrahim Ağa Evi & Ahşap & & $\mathrm{x}$ & & $\mathrm{x}$ & 86 & 168 & 3 & $\mathrm{x}$ & \\
\hline 11. Birincioğlu Evi & Ahşap & & $\mathrm{x}$ & & $\mathrm{x}$ & 97 & 166 & 3 & $\mathrm{x}$ & \\
\hline 12. Benzinci Mustafa Evi & Ahşap & & $\mathrm{x}$ & & $\mathrm{x}$ & 88 & 176 & 5 & $\mathrm{x}$ & \\
\hline 13. Veli Sezgin Evi & Ahşap & & $\mathrm{x}$ & & $\mathrm{x}$ & 87 & 164 & 3 & $\mathrm{x}$ & \\
\hline 14. Bekir Efendi Evi & Ahşap & & $\mathrm{x}$ & & $\mathrm{x}$ & 86 & 164 & 3 & $\mathrm{x}$ & \\
\hline 15. Sonay Çavuşoğlu Evi & Ahşap & & $\mathrm{x}$ & & $\mathrm{x}$ & 91 & 176 & 3 & $\mathrm{x}$ & \\
\hline 16. Mehmet Saltoğlu Konağ & Ahşap & & $\mathrm{x}$ & & $\mathrm{x}$ & 81 & 178 & 3 & $\mathrm{x}$ & \\
\hline 17. Ömer Türer Konağ 1 & Ahşap & & $\mathrm{x}$ & & $\mathrm{x}$ & 86 & 168 & 5 & $\mathrm{x}$ & \\
\hline
\end{tabular}

1.Kat ve Zemin kat pencere ölçülerinin ortalamaları, en yüksek ve düşük ölçüler grafiksel gösterimle Resim 8'de verilmiştir. 


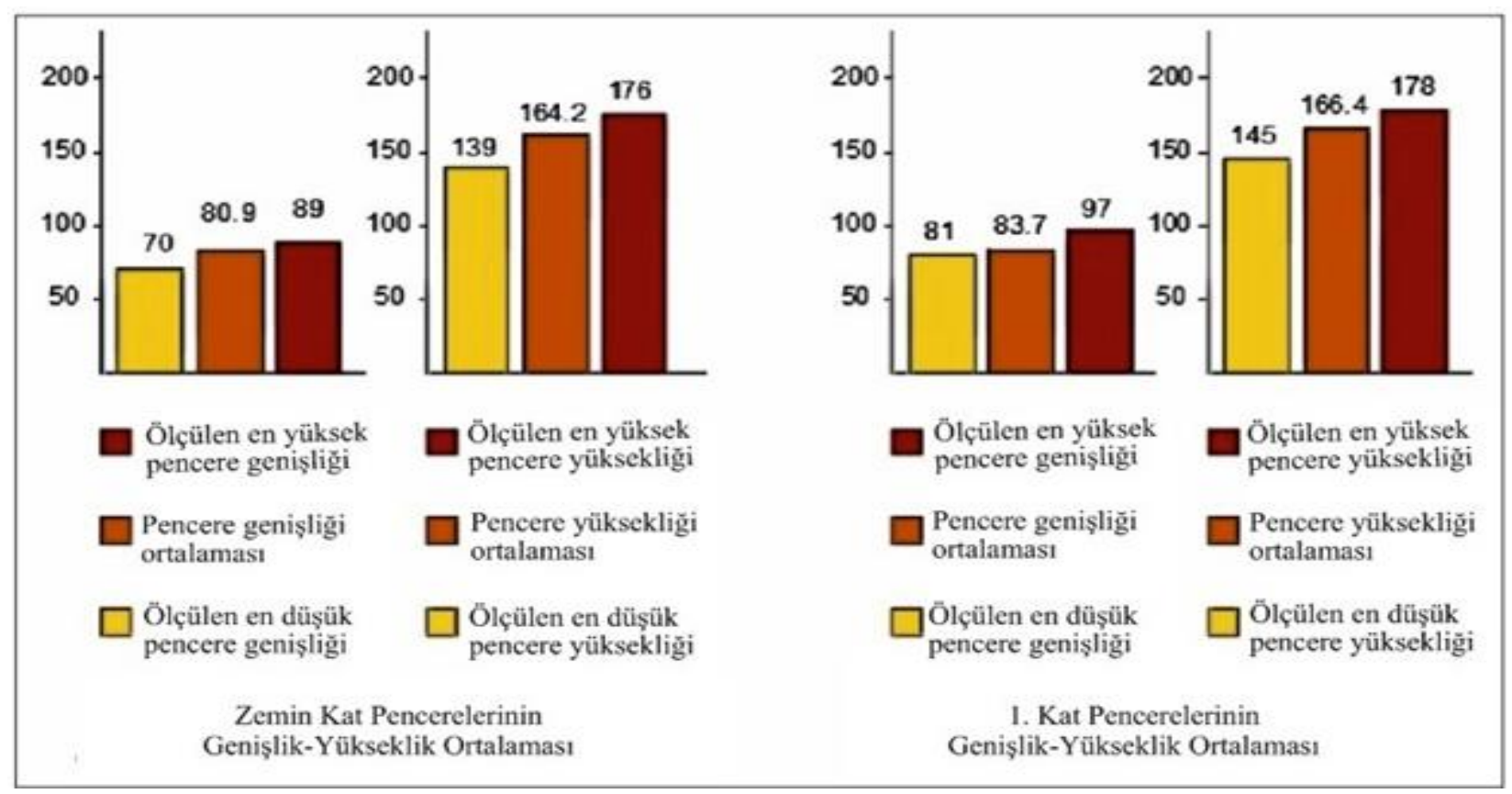

Resim 8. 1.Kat ve Zemin Kat Pencere Ölçülerinin Ortalamaları

Orta Mahallede incelenen 17 tescilli evin zemin ve birinci katlarına ait mevcut durum, söve çeşidi, yapım tekniği, süsleme, koruma durumu akademik çalışmalarda kabul görmüş envanter form uygulanarak tablolaştırılmıştır (Tablo 4).

Tablo 4. Araştırmada İncelenen Evler ve Pencerelerin Özellikleri

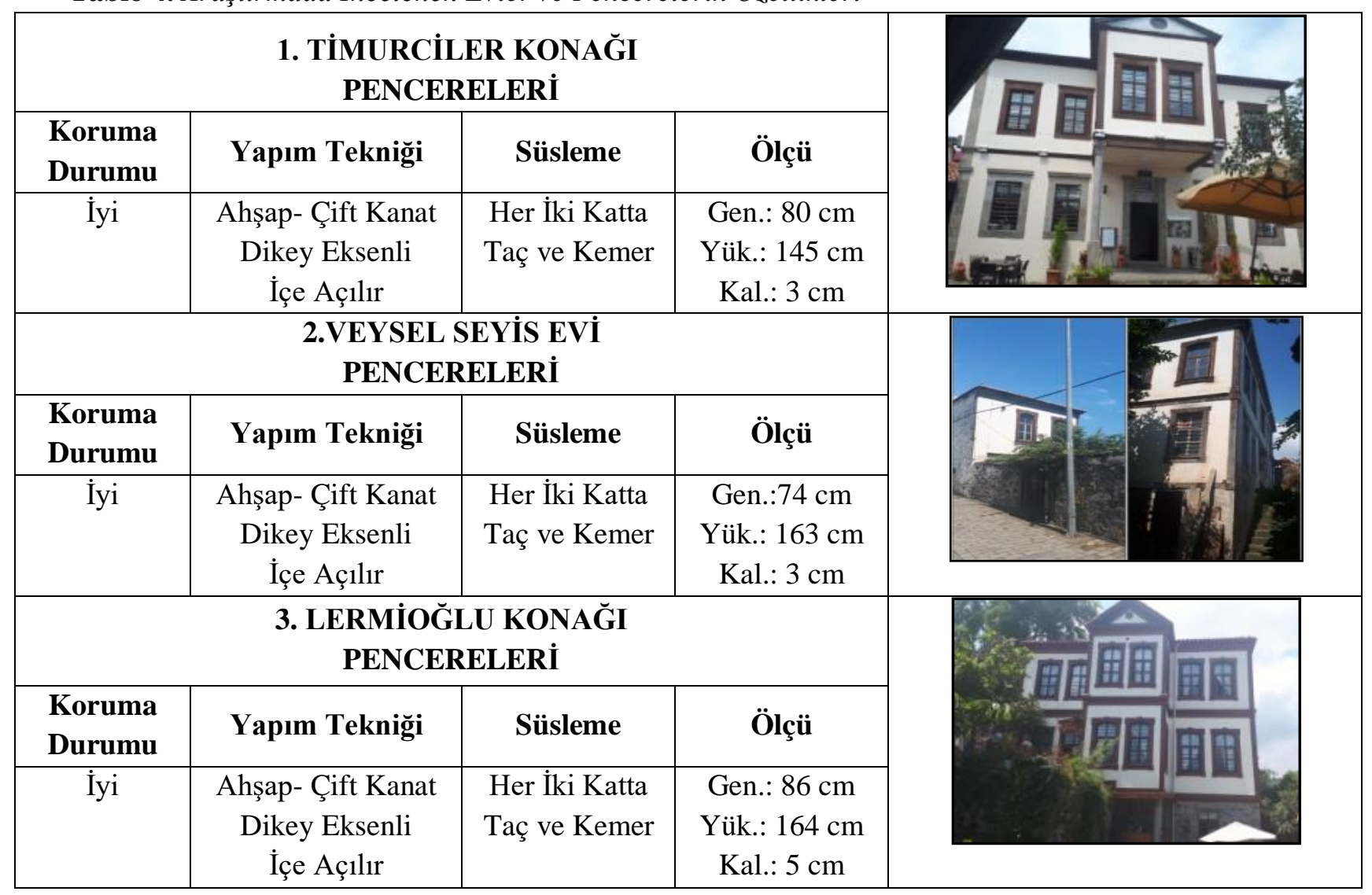




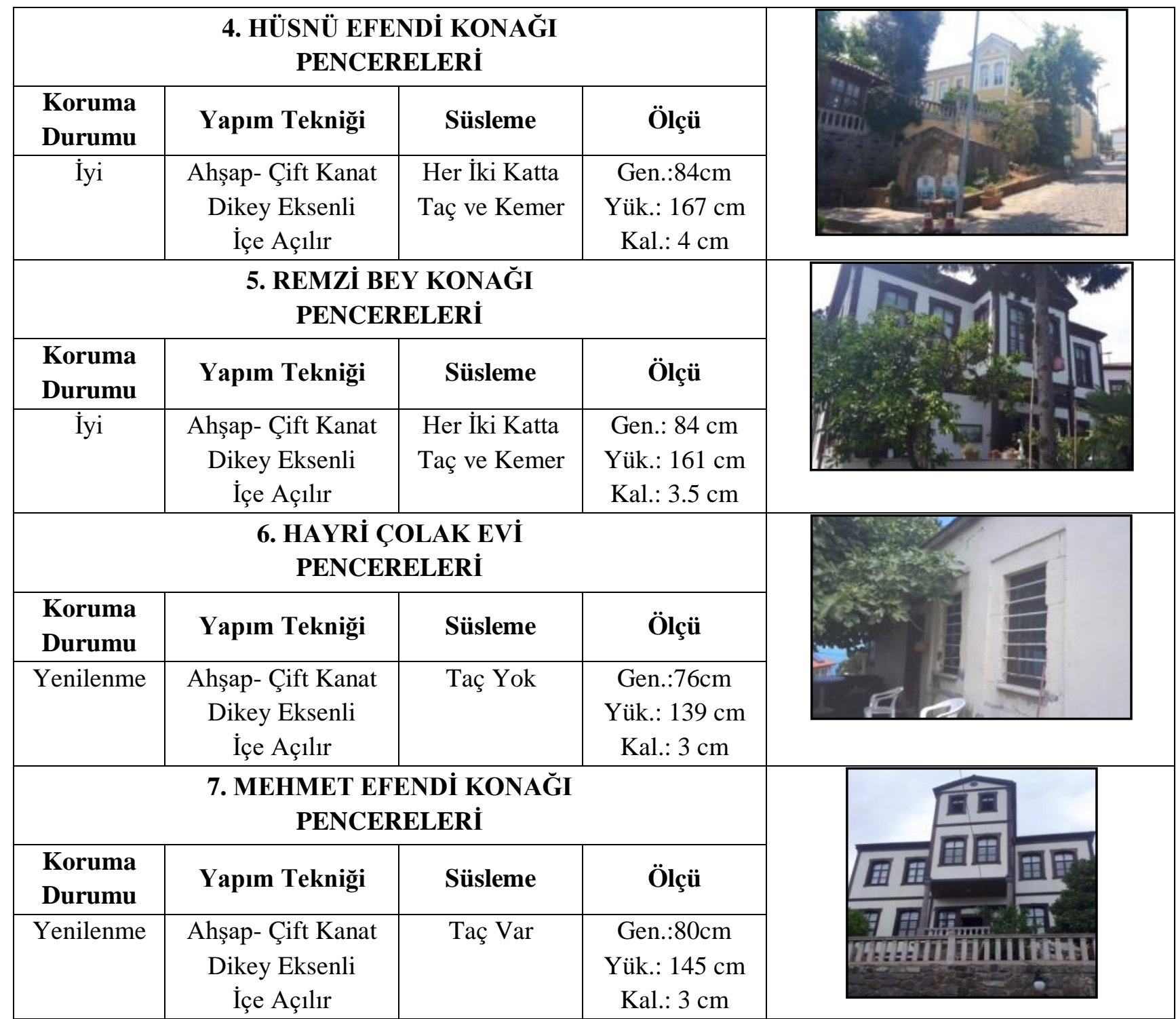


Tablo 4. Araştırmada İncelenen Evler ve Pencerelerin Özellikleri (Devamı)

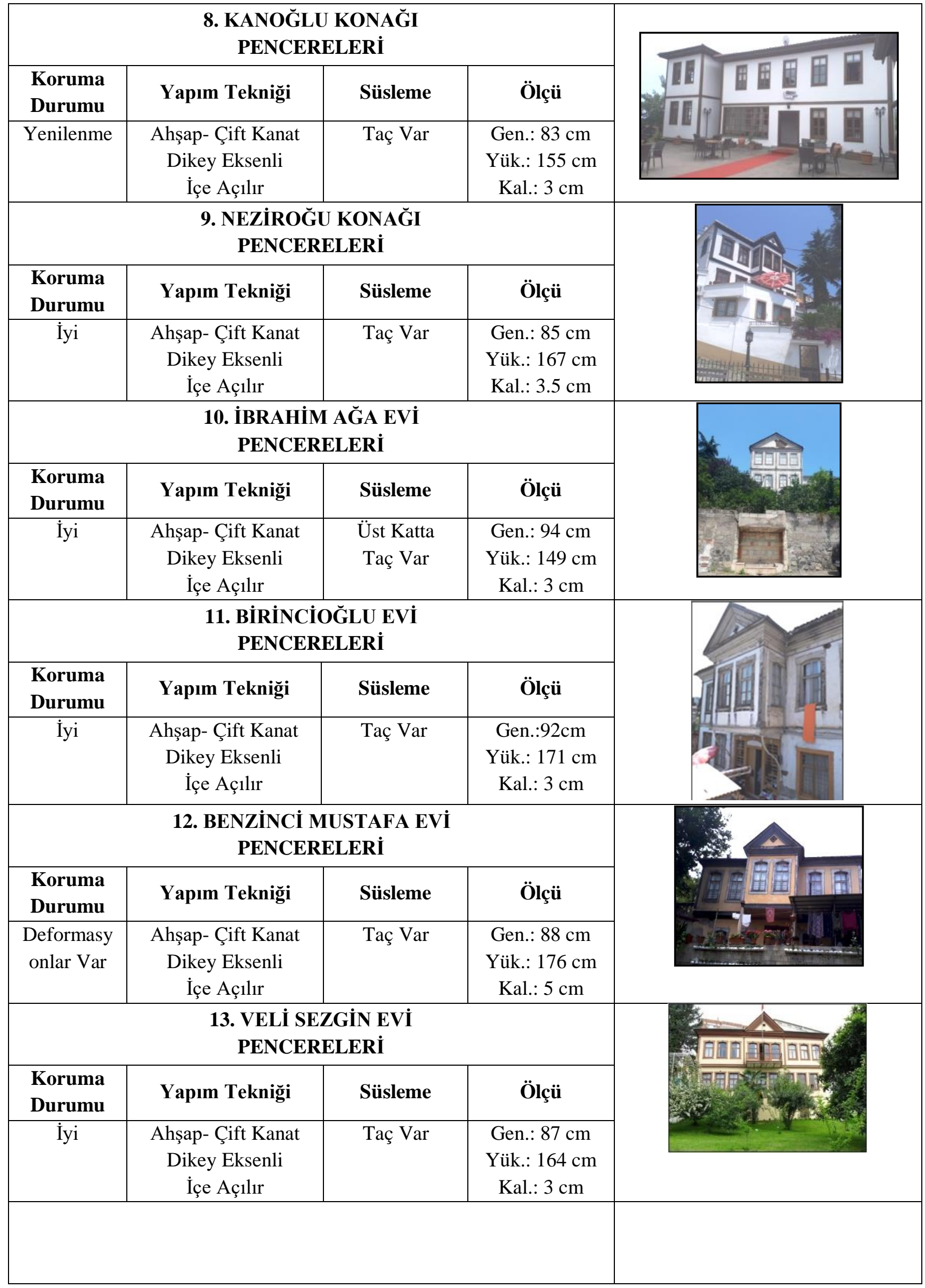




\begin{tabular}{|c|c|c|c|}
\hline \multicolumn{3}{|c|}{ 14. BEKİR EFENDİ KONAĞI } \\
PENCERELERİ \\
\hline $\begin{array}{c}\text { Koruma } \\
\text { Durumu }\end{array}$ & Yapım Tekniği & Süsleme & Ölçü \\
\hline İyi & $\begin{array}{c}\text { Ahşap- Çift Kanat } \\
\text { Dikey Eksenli } \\
\text { İçe Açılır }\end{array}$ & Taç Var & $\begin{array}{c}\text { Gen.: } 86 \mathrm{~cm} \\
\text { Yük.: } 167 \mathrm{~cm} \\
\text { Kal.: } 3 \mathrm{~cm}\end{array}$ \\
\hline
\end{tabular}

Tablo 4. Araştırmada İncelnen Evler ve Pencerelerin Özellikleri (Devamı)

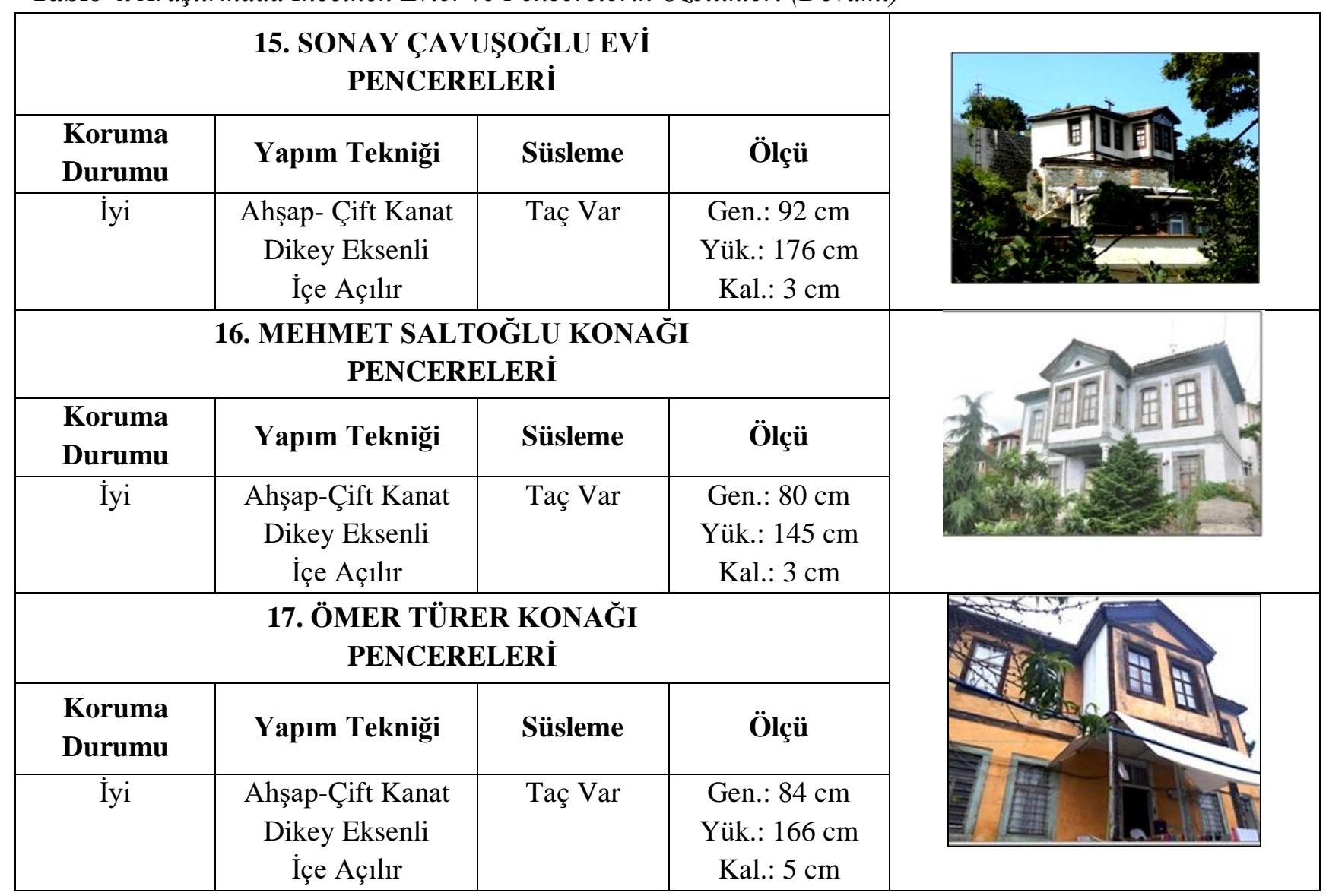

\section{SONUÇ VE ÖNERILLER}

Doğu Karadeniz bölgesinde yer alan Orta Mahallede incelenen Türk evleri bölgenin iklimi mimariyi de etkilemiştir. Yağışı bol ve gür ormanlara sahip olan coğrafyada ahşap kullanımı evlerin strüktüründe, cephe, iç mekân ve sabit donatı elemanlarının da görüldüğü gibi özellikle pencere sövelerinde, taçlarında ana malzeme olarak karşımıza çıkmaktadır.

Evlerin manzaraya konumlanmış olması Geleneksel Türk evlerine ait ortak özelliktir. Cephelerinde çıkma-alınlık-pencere-kapı gibi elemanların cephedeki oranları ve uyumu görülmektedir. Pencerelerin evlerin oda genişliğinde bulunan çıkmalarının ön cephesinde 2, her iki yanında 1 ya da 2 adet sıralanması Orta Mahalle Türk evlerinin cephesel karakteristik farklılı̆̆ını ortaya koymaktadır. Ayrıca çıkmanın etrafında konumlanan pencereler, iç mekândaki sofa alanına manzarayı yansıtarak hem ferah bir ortam hem gün ışığından yararlanılmasını sağlamıştır. Görsel olarakestetik bir değer kazandırmıştır.

Orta Mahalledeki Türk evlerinin pencere söveleri, alınlıkları ile uyum içerisinde genel itibariyle 
sade ve yalın tasarımın ürünüdür. Söve üzerinde işlemelere rastlanılmamıştır. Literatürdeki farklı coğrafyalarda bulunan Türk evlerinin pencerelerinde de görülen, mahremiyet anlayışının hakim olduğuve estetik görünüm katan ahşap ya da demir parmaklıklar Orta Mahalle Türk evlerinde de görülmektedir. Bu parmaklıkların dış cephede görsel bir bütünlük oluşturan senkronizasyonu göze çarpmaktadır. Parmaklıklar bir süs öğesi ya da yinelenen bir eleman olarak özellikle zemin kat pencerelerinde bulunmaktadir.

Zemin ve 1.kat pencereleri genelinde çift kanatlı, üst kısmı kanatları ise sabittir. Giyotin ve tepe pencerelerine rastlanmamıştır. Özellikle literatürde Karadeniz Bölgesi'nde görülen tepe pencereleri bakımından Orta Mahalle'deki Türk evleri farklılık göstermektedir. İncelenen 17 evin hiçbirinde tepe pencerelerine rastlanılmamıştır.

Genel itibariyle cephesel oranın söz konusu olduğu yapılarda, cumbanın iki yanında yer alan pencereler, ön cephesinde yer alan pencerelere göre daha dardır. Her ev kapı-pencere-çıkma ve bütünündeki kompozisyonla $1 / 2$ 'lik oranı sağladığı görülür. Bu oran bakımından diğer coğrafyalara ait Türk evleriyle benzer özellik taşımaktadır.

Gelenelsel Türk evlerinin iç mekânlarında pencerelerin bittiği alt sınır sedirlerin bittiği üst sınıra hızalanışı Orta Mahalle Türk evlerinde de görülmektedir. Bu ölçüsel uyum hem göze hem de işlevsel amaca hizmet etmektedir. Sofada sedirde oturan kişiye eğilmeden ya da kalkmadan manzarayı izleme imkân vermektedir.

Sonuç olarak; Orta Mahalle evlerindeki 24 tescilli evden 17 evin ulaşılabilir örnekleminin incelendiği araştırmada; Türk evinin tasarım ilkeleri açısından önemi olan ince yapı elemanlarından pencerelerin literatürde yer alan benzerlik ve farklılıkları tespit edilmiştir. Özellikle ince yapı elamanlarının Türk evinin karakteristik özelliklerini belirlemede önem arz ettiği hipotezi savunulan bu çalışmada, incelenen evler doğrultusunda Türk Evinin karakteristik özelliklerinin belirlemede pencerelerin önemli rol oynadığı doğrulanmıştır.

Pencere doğramalarının sövelerinin, taç bölümlerinin, kanatlarının, metal ya da ahşap parmaklıklarının zaman içerisinde deformasyona uğramaması için aslına uygun malzemeler seçerek, sağlamlaştırılmalı ve montajı sağlanmalıdır. Bizden sonraki nesillere aktarılabilmesi için Türk evleri kapısıyla, penceresiyle, iç mekân donatılarıyla bir bütündür. Bu bütünlüğü uygun onarım malzemeleri ile doğru restorasyon gerçekleştirerek korumak gerekir.

\section{KAYNAKÇA}

Akın., S. E. \& Ertürk., S. \& Özen., H. (2013). Geleneksel Akçaabat evleri miras değerleri dünden bugüne akçaabat sempozyumu. Akçaabat Belediyesi Kültür Yayınları.

Arat., Y. (2011). Geleneksel Türk evi iç mekân donatılarının antropometrik verilere dayalı analizi; Konya evler. (Yayımlanmamış Doktora Tezi). Selçuk Üniversitesi Fen Bilimleri Enstitüsü.

Azezli., G, S. (2009). 19.yy'da osmanlı konut mimarisinde iç mekân kurgusunun safranbolu evleri örneğinde irdelenmesi. (Yayımlanmamış Yüksek Lisans Tezi). İstanbul Kültür Üniversitesi Fen Bilimleri Enstitüsü.

Eldem., H.S. (1968). Türk evi plân tipleri. İTÜ Yayınları.

Göğebakan., Y. (2014). Karakteristik bir değer olan geleneksel Türk Evi'nin oluşumunu belirleyen unsurlar ve bu evlerin genel özellikleri. İnönü Üniversitesi Kültür ve Sanat Dergisi, 1(1), 41-55.

Hidayetoğlu., M, L. (2013). Geleneksel Türk Evi donatı elemanlarının restorasyonu ve çağdaş yapılarda yeniden kullanımı: bir şerbetlik örneği. SDÜ Fen Edebiyat Fakültesi Sosyal Bilimler Dergisi, (28), 291301. 
Kahraman., B. (1997). Geleneksel Türk odasında ahşap iç mimari elemanları. (Yayımlanmamış Yüksek Lisans Tezi). M.S.G.S.Ü. Fen Bilimleri Enstitüsü.

Küçükerman., Ö. (1985). Kendi mekânının arayışı içinde Türk Evi. Türkiye Turing ve Otomobil Kurumu Yayını.

Ünver., S. (1983). Dr. Rıfat Osman'a göre Edirne evleri. Türkiye Turing ve Otomobil Kurumu Yayınları.

Yürekli., H. \& Yürekli., F. (2005). Türk evi gözlemler ve yorumlar. Yap1 Endüstri Merkezi.

URL-1.http://erdogankarakoc.blogcu.com/pvc-ve-pencere-tarihcesi-pencibaba/4901936 (Erişim Tarihi: 20.06.2019). 